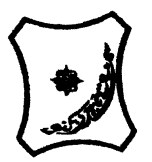

Bayero Journal of Pure and Applied Sciences, 10(1): 226 - 230

ISSN 2006 - 6996

\title{
INDUCED-GROWTH AND YIELD RESPONSES TO SEASONAL VARIATION BY SODIUM AZIDE IN TOMATO (Lycopersicon esculentum MILL.)
}

\author{
*Aminu, Y., ${ }^{1}$ Bala, B. U. ${ }^{1}$, Kabiru, H. I., and Musbahu, A. A. \\ ${ }^{1}$.Department of Biological Sciences, College of Arts, Science and Remedial Studies, Kano, Nigeria \\ ${ }^{2}$.Department of Physical Sciences, College of Arts, Science and Remedial Studies, Kano, Nigeria \\ ${ }^{*}$ Corresponding Author: aminuyahayafagge@gmail.com; GSM: +2347035347997
}

\section{ABSTRACT}

The mutagenic effect of various concentrations of sodium azide on some selected quality traits of three varieties of tomato was investigated with the aim of improving the quality and quantity of the traits of economic importance. The seeds of three tomato varieties namely: Roma, UC and a Local variety were treated with four different concentrations of sodium azide $(0.1 \mathrm{mM}, 1.0 \mathrm{mM}, 2.0 \mathrm{mM}$ and $0.0 \mathrm{mM}$ as control) via pre-soaking during both the wet and dry seasons. The results obtained revealed highly significant difference $(P \leq 0.01)$ in the effects of various concentrations of sodium azide on the number of leaves, leaf area, number of fruits, fruit weight, pericarp thickness, number of seeds/fruit and $\mathrm{pH}$ of the fruit juices. Significant improvement $(P \leq 0.05)$ was recorded on fruit diameter. More so, significant differences were found in the interactions of the varieties to the mutagenic treatments during the rainy season than the dry season. The interaction showed that all the mutants treated with $0.1 \mathrm{mM}$ concentration have the highest response in all the selected traits during rainy season except fruit diameter. Similarly, all the $1.0 \mathrm{mM}$ treated mutants showed highest response during rainy season except in leaf area where highest response was found in dry season. Similar result was found in $2.0 \mathrm{mM}$ treated mutants. We therefore concluded that $0.1 \mathrm{Mm}$ sodium azide concentration improves important quality traits of tomato more especially variety UC as it responds significantly to sodium azide and that, the mutant tomato could be grown both during the rainy and dry seasons.

Key Words: Concentrations, Mutation, Sodium Azide, Tomato

\section{INTRODUCTION}

Tomato (Lycopersicon lycopersicum Mill.) is a crop of high importance in many countries (FAO, 1998).It belongs to the small genus Lycopersicon consisting of nine species within the large family Solanaceae (Purseglove, 1968; Hille et al., 1989). Tomato isnowadays one of the major vegetable crops cultivatedthroughout the world, grown in a wide range of environments comprising natural and protected conditions (Dhaliwal et al., 2002) of both the tropical, sub-tropical and temperate parts of the world. However, tomato is a classic example of a crop plant in which, until mid-century, germ-plasm resources was inadequate for significant crop improvement or major advantage in basic genetic research. These can be attributed to the selection force with consequent reduction in genetic variability; leading to difficulties experienced by breeders in finding the genes essential for desired improvements.

Ironically, despite the significance of tomato to the world economy and health status of a modern man, proper attention in terms of its improvement among the authorities concerned in Nigeria is lacking. Tomato is faced with the problem of seizure within some period of the year; especially in the guinea and sudan savanna zones of Nigeria. Since tomato is one of the most important crops, special measures are therefore needed to increase the range of genetic variation (Rick, 1989). The lack of improved varieties that can withstand the environmental stress of the time with increased vigor posed a great challenge to tomato improvements in Nigeria.

Mutation on the other hand, was applied to increase yield, stress tolerance and reduce agronomic in-puts (Ahloowalia and Maluszynski, 2001). The possibility of applying mutation to improve fruit quality has been scarcely investigated. This research exploredinduced mutation using sodium azide to improve the quality traits of cultivated tomato so as to make the plant available for local consumption throughout the year in the savanna ecological zone of Nigeria. 


\section{MATERIALS AND METHODS}

Study Site

The research was conducted in the Green House of the Botanical Garden of the Department of Biological Sciences, Ahmadu Bello University Zaria (Lat $11^{0} 12^{1} \mathrm{~N}$, Long $7^{0}, 37^{1} \mathrm{E}$, Alt $550-700 \mathrm{~m}$ above sea level) (Anonymous, 2014).

Sources of the Sées

Seeds of three varieties of cultivated tomato (Roma, UC and a localvariety) were collected from the Institute for Agricultural Research (I.A.R), Ahmadu Bello University Zaria, Nigeria. Treatment and Experimental Design

The seeds of three tomato varieties (Roma, UC and one local variety) were treated with four different concentrations of sodium azide $(0.1 \mathrm{mM}, \quad 1.0 \mathrm{mM}, \quad 2.0 \mathrm{mM}$ and $0.0 \mathrm{mM}$ as control)via pre-soaking for four hours as described by Asmahan (1993). The controls were pre-soaked in distill water. The treated plants were washed in running water for one hour and allowed to dry under room temperature for 24 hours. The seeds were then sown in polythene bags arranged in a
Completely Randomized Design (CRD) with three repetitions and grown during the 2013 rainy season and 2013/2014 dry season. Data were obtained from number of leaves, leaf area, number of fruits/plant, diameter of the fruits, thickness of pericarp, number of seeds/fruit, fruit weight and $\mathrm{pH}$ values of the fruit juice.

Data Analysis

All the data obtained were analyzed using Analysis of Variance. The means were separated using Duncan's Multiple Range Test (Duncan, 1955).

\section{RESULTS}

The result for the analysis of variance following treatment of tomato seeds with various concentrations of sodium azide during the wet season was presented in Table 1. The result indicated high significant difference $(P \leq 0.01)$ in the effect of various concentrations of sodium azide on all the selected tomato traits except pericarp thickness and fruit diameter; where no significant difference was found.

Table 1: Mean Squares for the Effects of Sodium Azide on Some Varieties of Tomato in Wet Season

\begin{tabular}{|c|c|c|c|c|c|c|c|c|c|}
\hline $\begin{array}{c}\text { Sources of } \\
\text { Variation }\end{array}$ & DF & $\begin{array}{c}\text { Number } \\
\text { of } \\
\text { Leaves }\end{array}$ & $\begin{array}{l}\text { Leaf } \\
\text { Area } \\
\left(\mathrm{cm}^{2}\right)\end{array}$ & $\begin{array}{c}\text { Number } \\
\text { of } \\
\text { Fruits/pla } \\
\text { nt }\end{array}$ & $\begin{array}{l}\text { Fruit } \\
\text { Weight } \\
\text { (g) }\end{array}$ & $\begin{array}{l}\text { Pericarp } \\
\text { Thickne } \\
\text { ss }(\mathrm{mm})\end{array}$ & $\begin{array}{c}\text { Number } \\
\text { of } \\
\text { Seeds/Fru } \\
\text { it } \\
\end{array}$ & $\begin{array}{c}\text { Fruit } \\
\text { Diamet } \\
\text { er }(\mathrm{m})\end{array}$ & $\mathrm{pH}$ \\
\hline Replication & 2 & $53.86^{* *}$ & $129.08^{\mathrm{ns}}$ & $4.39^{\mathrm{ns}}$ & $4.82^{\mathrm{ns}}$ & $0.05^{\mathrm{ns}}$ & $694.17^{*}$ & $0.36^{*}$ & $0.03^{*}$ \\
\hline $\begin{array}{c}\text { Concentrati } \\
\text { on }\end{array}$ & 3 & $\underset{* *}{171.27}$ & $\underset{* *}{1261.87}$ & $99.38^{* *}$ & $\underset{* *}{251.63}$ & $0.08^{\mathrm{ns}}$ & $\begin{array}{c}4384.26^{*} \\
*\end{array}$ & $0.19^{\text {ns }}$ & $\begin{array}{c}0.40^{*} \\
*\end{array}$ \\
\hline Error & $\begin{array}{c}14 \\
2\end{array}$ & 3.58 & 27.27 & 3.05 & 10.92 & 0.07 & 140.81 & 0.07 & $\begin{array}{c}0.00 \\
8\end{array}$ \\
\hline
\end{tabular}

Similarly, the result for the analysis of variance of the effect of various concentrations of sodium azide during the dry season revealed highly significant difference $(P \leq 0.01)$ on all the selected tomato traits except on fruit diameter where no significant difference was found (Table 2).

Table 2: Mean Squares for the Effects of Sodium Azide on Some Varieties of Tomato in Dry Season

\begin{tabular}{|c|c|c|c|c|c|c|c|c|c|}
\hline $\begin{array}{l}\text { Sources of } \\
\text { Variation }\end{array}$ & DF & $\begin{array}{c}\text { Number } \\
\text { of } \\
\text { Leaves }\end{array}$ & $\begin{array}{l}\text { Leaf } \\
\text { Area } \\
\left(\mathrm{cm}^{2}\right)\end{array}$ & $\begin{array}{c}\text { Number } \\
\text { of } \\
\text { Fruits/pla } \\
\text { nt }\end{array}$ & $\begin{array}{c}\text { Fruit } \\
\text { Weight } \\
\text { (g) }\end{array}$ & $\begin{array}{l}\text { Pericarp } \\
\text { Thickne } \\
\text { ss }(\mathrm{mm})\end{array}$ & $\begin{array}{c}\text { Number } \\
\text { of } \\
\text { Seeds/Fru } \\
\text { it }\end{array}$ & $\begin{array}{c}\text { Fruit } \\
\text { Diamet } \\
\text { er }(m)\end{array}$ & $\mathrm{pH}$ \\
\hline Replication & 2 & $10.95^{\mathrm{ns}}$ & $165.08^{*}$ & $7.68^{\text {ns }}$ & $70.26^{* *}$ & $0.10^{\mathrm{ns}}$ & $147.81^{\mathrm{ns}}$ & $0.04^{\mathrm{ns}}$ & $\underset{\mathrm{ns}}{0.001}$ \\
\hline $\begin{array}{c}\text { Concentrati } \\
\text { on }\end{array}$ & 3 & $\begin{array}{c}131.96 \\
* *\end{array}$ & $\begin{array}{c}1663.79 \\
* *\end{array}$ & $90.14^{* *}$ & $\begin{array}{c}141.05 \\
* *\end{array}$ & $0.58^{* *}$ & $\begin{array}{c}1569.06^{*} \\
*\end{array}$ & $0.11^{\mathrm{ns}}$ & $0.01^{* *}$ \\
\hline Error & $\begin{array}{c}14 \\
2\end{array}$ & 2.90 & 18.57 & 2.60 & 3.82 & 0.05 & 62.77 & 0.04 & 0.03 \\
\hline
\end{tabular}


However, the result for the combined analysis of variance (Table 3 ) showed highly significant difference $(P \leq 0.01)$ in the effect of various concentrations of sodium azide on all the selected traits except on fruit diameter where the effect is significant $(P \leq 0.05)$. Similarly, the effect of the different concentrations of sodium azide was highly significant $(P \leq 0.01)$ among the varieties in terms of fruit diameter; where the effect is significant $(P \leq 0.05)$ and pericarp thickness (where no significant difference was found). Furthermore, highly significant difference $(P \leq 0.01)$ was found among the seasons in terms of fruit weight, seeds number and $\mathrm{pH}$ but significant in terms of leaf area. No significant difference was found among the seasons in terms of leaf number, fruit number, pericarp thickness and fruit diameter. However, no significant difference was found in the interactions of the concentrations and varieties and concentrations and seasons on the selected traits (except on seeds number). But highly significant difference was found in the interactions of the variety and seasons on leaf and fruit number and significant $(\mathrm{P} \leq 0.05)$ on leaf area and $\mathrm{pH}$.

Table 3: Mean Squares for the Combined Effects of Sodium Azide on Some Varieties of Tomato in Two Different Seasons

\begin{tabular}{|c|c|c|c|c|c|c|c|c|c|}
\hline $\begin{array}{l}\text { Sources of } \\
\text { Variation }\end{array}$ & DF & $\begin{array}{l}\text { Number } \\
\text { of } \\
\text { Leaves }\end{array}$ & $\begin{array}{l}\text { Leaf } \\
\text { Area } \\
\left(\mathrm{cm}^{2}\right)\end{array}$ & $\begin{array}{l}\text { Number } \\
\text { of Fruits }\end{array}$ & $\begin{array}{l}\text { Fruit } \\
\text { Weight } \\
\text { (g) }\end{array}$ & $\begin{array}{l}\text { Pericarp } \\
\text { Thicknes } \\
\mathrm{s}(\mathrm{mm})\end{array}$ & $\begin{array}{l}\text { Number of } \\
\text { Seeds/Frui } \\
\mathrm{t}\end{array}$ & $\begin{array}{l}\text { Fruit } \\
\text { Diamete } \\
r(\mathrm{~m})\end{array}$ & $\mathrm{pH}$ \\
\hline Replication & 2 & $27.83^{* *}$ & $60.4^{\mathrm{ns}}$ & $11.87^{*}$ & $55.92^{* *}$ & $0.01^{\mathrm{ns}}$ & $476.72^{*}$ & $0.12^{\mathrm{ns}}$ & $0.01^{\mathrm{ns}}$ \\
\hline $\begin{array}{l}\text { Concentratio } \\
\mathrm{n}\end{array}$ & 3 & $300.33^{*}$ & $2898^{* *}$ & ${ }_{*}^{188.59 *}$ & $383^{* *}$ & $0.53^{* *}$ & $5594^{* *}$ & $0.28^{*}$ & $0.92^{* *}$ \\
\hline Variety & 2 & $\underset{*}{226.86^{*}}$ & $1376^{* *}$ & $37.26^{* *}$ & ${ }_{*}^{564.34^{*}}$ & $0.07^{\mathrm{ns}}$ & $2892^{* *}$ & $0.20^{*}$ & $0.42^{* *}$ \\
\hline Seasons & 1 & $5.67^{\mathrm{ns}}$ & $\begin{array}{l}126.19 \\
*\end{array}$ & $0.01^{\mathrm{ns}}$ & $\begin{array}{l}189.84^{*} \\
*\end{array}$ & $0.20^{\mathrm{ns}}$ & $6868.16^{* *}$ & $0.08^{\text {ns }}$ & $0.45^{* *}$ \\
\hline Conc $x$ Var & 6 & $1.38^{\mathrm{ns}}$ & $44.98^{\mathrm{ns}}$ & $3.19^{\mathrm{ns}}$ & $14.17^{\mathrm{ns}}$ & $0.05^{\mathrm{ns}}$ & $76.59^{\mathrm{ns}}$ & $0.07^{\text {ns }}$ & ${ }_{s}^{0.009^{n}}$ \\
\hline Conc $x$ Seas & 3 & $2.89^{\mathrm{ns}}$ & $27.14^{\mathrm{ns}}$ & $0.91^{\mathrm{ns}}$ & $9.67^{\mathrm{ns}}$ & $0.12^{\mathrm{ns}}$ & $359.19^{*}$ & $0.01^{\mathrm{ns}}$ & $0.01^{\mathrm{ns}}$ \\
\hline Var x Seas & 2 & ${ }_{*}^{135.17^{*}}$ & $\begin{array}{l}113.42 \\
*\end{array}$ & $95.56^{* *}$ & $12.12^{\mathrm{ns}}$ & $0.04^{\mathrm{ns}}$ & $117.05^{\mathrm{ns}}$ & $0.001^{\mathrm{ns}}$ & $0.07^{*}$ \\
\hline $\begin{array}{l}\text { Conc x Var } \mathrm{x} \\
\text { Sea }\end{array}$ & 6 & $1.54^{\mathrm{ns}}$ & $40.40^{\text {ns }}$ & $9.88^{\mathrm{ns}}$ & $4.03^{\mathrm{ns}}$ & $0.11^{\mathrm{ns}}$ & $99.76^{\mathrm{ns}}$ & $0.005^{\mathrm{ns}}$ & $0.01^{\mathrm{ns}}$ \\
\hline Error & $\begin{array}{l}14 \\
2\end{array}$ & 3.21 & 25.89 & 2.78 & 7.53 & 0.05 & 105.50 & 0.06 & 0.01 \\
\hline
\end{tabular}

More so, the means for the effect of various concentrations of sodium azide on quality traits of tomato was presented in Table 4. The result revealed that, the mutants produced large number of leaves (14 to 17 leaves) that are larger in size $\left(12.06-24.55 \mathrm{~cm}^{2}\right)$ and produced 3-6 fruits that weigh $11.88-16.16 \mathrm{~g}$ with a pericarp thickness of $0.24-0.43 \mathrm{~mm}$. Similarly, the mutants produced 53-67 seeds per fruit with a diameter of $0.23-0.34 \mathrm{~m}$ and fruit juice $\mathrm{pH}$ of 4.16-4.38. The effect is concentration dependent, increases with decrease in concentration.

Table 4: The Effects of Sodium Azide Concentrations on the Selected Traits of Three Tomato Varieties

\begin{tabular}{ccccccccc}
\hline $\begin{array}{c}\text { Concentration } \\
(\mathrm{mM})\end{array}$ & $\begin{array}{c}\text { Number } \\
\text { of } \\
\text { Leaves }\end{array}$ & $\begin{array}{c}\text { Leaf } \\
\text { Area } \\
\left(\mathrm{cm}^{2}\right)\end{array}$ & $\begin{array}{c}\text { Number } \\
\text { of } \\
\text { Fruits }\end{array}$ & $\begin{array}{c}\text { Fruit } \\
\text { Weight } \\
(\mathrm{g})\end{array}$ & $\begin{array}{c}\text { Pericarp } \\
\text { Thickness } \\
(\mathrm{mm})\end{array}$ & $\begin{array}{c}\text { Number of } \\
\text { Seeds/Fruit }\end{array}$ & $\begin{array}{c}\text { Fruit } \\
\text { Diameter } \\
(\mathrm{m})\end{array}$ & $\begin{array}{c}\mathrm{pH} \\
0.03^{\mathrm{d}}\end{array}$ \\
\hline 0.0 & $11.64^{\mathrm{d}}$ & $7.83^{\mathrm{d}}$ & $2.03^{\mathrm{d}}$ & $9.93^{\mathrm{d}}$ & $0.21^{\mathrm{c}}$ & $45.01^{\mathrm{d}}$ & $0.17^{\mathrm{c}}$ & $4.07^{\mathrm{d}}$ \\
0.1 & $17.20^{\mathrm{a}}$ & $24.55^{\mathrm{a}}$ & $6.35^{\mathrm{a}}$ & $16.16^{\mathrm{a}}$ & $0.43^{\mathrm{a}}$ & $66.74^{\mathrm{a}}$ & $0.34^{\mathrm{a}}$ & $4.38^{\mathrm{a}}$ \\
1.0 & $15.46^{\mathrm{b}}$ & $18.43^{\mathrm{b}}$ & $4.12^{\mathrm{b}}$ & $13.79^{\mathrm{b}}$ & $0.30^{\mathrm{b}}$ & $60.29^{\mathrm{b}}$ & $0.26^{\mathrm{ba}}$ & $4.23^{\mathrm{b}}$ \\
2.0 & $13.92^{\mathrm{c}}$ & $12.06^{\mathrm{c}}$ & $2.92^{\mathrm{c}}$ & $11.88^{\mathrm{c}}$ & $0.24^{\mathrm{b}}$ & $52.64^{\mathrm{c}}$ & $0.23^{\mathrm{b}}$ & $4.16^{\mathrm{c}}$ \\
\hline Mean & 14.55 & 15.72 & 3.85 & 12.94 & 0.30 & 56.17 & 0.25 & 4.21 \\
\hline
\end{tabular}

N.B:*1Meanswithinthecolumnswiththesameletter(s)arenotsignificantlydifferent $(\mathrm{P} \leq 0.05)$

The result of the mean effect of the interaction of concentration with variety and season is presented in Table 5 . The result indicated that, the interactions makes all the three varieties of 
tomato to respond more to the mutagenic treatments during the rainy season than the dry season. The interaction showed pericarp thickness of the controls to have the highest response during the dry season. However, all the mutants treated with $0.1 \mathrm{mM}$ concentration showed highest response in all the selected traits during rainy season except fruit diameter. Similarly, all the $1.0 \mathrm{mM}$ treated mutants showed highest response during rainy season except in leaf area where highest response was found in dry season. Similar result was found in $2.0 \mathrm{mM}$ treated mutants.

Means for thelnteractions of the Effects of Concentration, Variety and Seasons on some Selected Tomato Traits

\begin{tabular}{|c|c|c|c|c|c|c|c|c|c|c|}
\hline $\begin{array}{l}\text { Concentration } \\
(\mathrm{mM})\end{array}$ & Variety & Season & $\begin{array}{c}\begin{array}{c}\text { Number } \\
\text { of } \\
\text { Leaves }\end{array} \\
\end{array}$ & $\begin{array}{l}\text { Leaf } \\
\text { Area } \\
\left(\mathrm{cm}^{2}\right)\end{array}$ & $\begin{array}{c}\text { Number } \\
\text { of } \\
\text { Fruits }\end{array}$ & $\begin{array}{c}\text { Fruit } \\
\text { Weight } \\
\text { (g) }\end{array}$ & $\begin{array}{l}\text { Pericarp } \\
\text { Thickness } \\
(\mathrm{mm})\end{array}$ & $\begin{array}{l}\text { Number of } \\
\text { Seeds/Fruit }\end{array}$ & $\begin{array}{c}\text { Fruit } \\
\text { Diameter } \\
(\mathrm{m})\end{array}$ & $\mathrm{pH}$ \\
\hline \multirow[t]{6}{*}{0.0} & Local & Dry & $9.00^{\mathrm{D} " 1}$ & $7.00^{\mathrm{a}}$ & $1.33^{\mathrm{b}}$ & $8.55^{\mathrm{D}}$ & $0.60^{\mathrm{a}}$ & $38.55^{\mathrm{D}}$ & $0.32^{\mathrm{b}}$ & $3.90^{b}$ \\
\hline & Local & Rainy & $11.11^{\mathrm{a}}$ & $6.83^{\mathrm{b}}$ & $2.00^{\mathrm{a}}$ & $9.72^{a}$ & $0.41^{\mathrm{b}}$ & $40.88^{a}$ & $0.37^{\mathrm{a}}$ & $4.12^{\mathrm{a}}$ \\
\hline & Roma & Dry & $10.66^{\mathrm{b}}$ & $6.16^{\mathrm{a}}$ & $1.77^{\mathrm{b}}$ & $8.00^{\mathrm{b}}$ & $0.60^{\mathrm{a}}$ & $39.22^{b}$ & $0.25^{\mathrm{b}}$ & $4.04^{a}$ \\
\hline & Roma & Rainy & $11.55^{\mathrm{a}}$ & $5.65^{\mathrm{b}}$ & $2.55^{\mathrm{a}}$ & $9.44^{\mathrm{a}}$ & $0.29^{b}$ & $46.55^{a}$ & $0.31^{\mathrm{a}}$ & $4.10^{\mathrm{a}}$ \\
\hline & UC & Dry & $15.11^{\mathrm{a}}$ & $9.83^{a}$ & $2.77^{\mathrm{a}}$ & $11.22^{\mathrm{a}}$ & $0.40^{\mathrm{a}}$ & $48.33^{a}$ & $0.39^{a}$ & $4.08^{\mathrm{a}}$ \\
\hline & UC & Rainy & $12.44^{\mathrm{a}}$ & $11.50^{\mathrm{a}}$ & $1.77^{\mathrm{a}}$ & $12.66^{\mathrm{a}}$ & $0.30^{\mathrm{a}}$ & $56.55^{a}$ & $0.42^{\mathrm{a}}$ & $4.21^{\mathrm{a}}$ \\
\hline \multirow[t]{6}{*}{0.1} & Local & Dry & $15.11^{\mathrm{b}}$ & $26.50^{\mathrm{a}}$ & $4.00^{\mathrm{b}}$ & $12.55^{\mathrm{D}}$ & $0.15^{\mathrm{D}}$ & $53.66^{\mathrm{D}}$ & $0.17^{\mathrm{a}}$ & $4.30^{\mathrm{b}}$ \\
\hline & Local & Rainy & $17.44^{\mathrm{a}}$ & $18.16^{\mathrm{D}}$ & $5.77^{\mathrm{a}}$ & $17.88^{\mathrm{a}}$ & $0.26^{a}$ & $70.77^{\mathrm{a}}$ & $0.17^{a}$ & $4.33^{\mathrm{a}}$ \\
\hline & Roma & Dry & $15.22^{\mathrm{b}}$ & $18.16^{\mathrm{b}}$ & $5.33^{\mathrm{b}}$ & $12.11^{\mathrm{b}}$ & $0.17^{\mathrm{b}}$ & $56.77^{\mathrm{b}}$ & $0.21^{\mathrm{a}}$ & $4.33^{\mathrm{b}}$ \\
\hline & Roma & Rainy & $17.55^{\mathrm{a}}$ & $22.00^{\mathrm{a}}$ & $8.88^{\mathrm{a}}$ & $13.88^{\mathrm{a}}$ & $0.25^{\mathrm{a}}$ & $81.88^{\mathrm{a}}$ & $0.18^{\mathrm{b}}$ & $4.40^{\mathrm{a}}$ \\
\hline & UC & Dry & $20.33^{\mathrm{a}}$ & $31.83^{\mathrm{a}}$ & $9.33^{\mathrm{a}}$ & $19.33^{\mathrm{b}}$ & $0.28^{\mathrm{b}}$ & $69.00^{\mathrm{b}}$ & $0.15^{\mathrm{a}}$ & $4.41^{\mathrm{b}}$ \\
\hline & UC & Rainy & $17.55^{\mathrm{b}}$ & $30.66^{\mathrm{b}}$ & $4.77^{\mathrm{b}}$ & $22.21^{a}$ & $0.50^{\mathrm{a}}$ & $80.33^{\mathrm{a}}$ & $0.14^{\mathrm{b}}$ & $4.54^{\mathrm{a}}$ \\
\hline \multirow[t]{6}{*}{1.0} & Local & Dry & $12.77^{\mathrm{b}}$ & $19.33^{\mathrm{a}}$ & $2.55^{\mathrm{b}}$ & $11.11^{\mathrm{D}}$ & $0.28^{a}$ & $49.55^{b}$ & $0.13^{\mathrm{b}}$ & $4.05^{b}$ \\
\hline & Local & Rainy & $15.77^{\mathrm{a}}$ & $12.66^{\mathrm{b}}$ & $4.11^{\mathrm{a}}$ & $14.00^{\mathrm{a}}$ & $0.19^{b}$ & $63.88^{\mathrm{a}}$ & $0.22^{\mathrm{a}}$ & $4.22^{\mathrm{a}}$ \\
\hline & Roma & Dry & $13.66^{\mathrm{b}}$ & $14.66^{\mathrm{a}}$ & $4.00^{\mathrm{b}}$ & $10.66^{\mathrm{b}}$ & $0.22^{a}$ & $51.88^{\mathrm{b}}$ & $0.17^{\mathrm{b}}$ & $4.25^{\mathrm{a}}$ \\
\hline & Roma & Rainy & $15.44^{\mathrm{a}}$ & $14.66^{\mathrm{s}}$ & $4.66^{\mathrm{a}}$ & $12.11^{\mathrm{a}}$ & $0.22^{\mathrm{a}}$ & $65.77^{\mathrm{a}}$ & $0.25^{\mathrm{a}}$ & $4.23^{\mathrm{b}}$ \\
\hline & UC & Dry & $18.77^{\mathrm{a}}$ & $25.94^{\mathrm{a}}$ & $6.22^{\mathrm{a}}$ & $16.55^{\mathrm{b}}$ & $0.25^{\mathrm{b}}$ & $60.55^{\mathrm{b}}$ & $0.28^{\mathrm{b}}$ & $4.27^{\mathrm{b}}$ \\
\hline & UC & Rainy & $16.33^{b}$ & $23.33^{\mathrm{b}}$ & $3.22^{\mathrm{b}}$ & $18.33^{\mathrm{a}}$ & $0.28^{a}$ & $70.11^{a}$ & $0.30^{\mathrm{a}}$ & $4.38^{\mathrm{a}}$ \\
\hline \multirow[t]{6}{*}{2.0} & Local & Dry & $12.06^{\mathrm{D}}$ & $11.16^{\mathrm{a}}$ & $2.11^{\mathrm{b}}$ & $9.88^{\mathrm{b}}$ & $0.55^{\mathrm{a}}$ & $45.11^{\mathrm{b}}$ & $0.20^{\mathrm{b}}$ & $4.02^{b}$ \\
\hline & Local & Rainy & $12.88^{\mathrm{a}}$ & $9.66^{\mathrm{b}}$ & $2.44^{\mathrm{a}}$ & $11.77^{\mathrm{a}}$ & $0.24^{\mathrm{b}}$ & $48.00^{\mathrm{a}}$ & $0.21^{\mathrm{a}}$ & $4.16^{\mathrm{a}}$ \\
\hline & Roma & Dry & $12.33^{b}$ & $9.50^{\mathrm{a}}$ & $2.44^{\mathrm{b}}$ & $9.44^{\mathrm{b}}$ & $0.20^{\mathrm{b}}$ & $44.11^{\mathrm{b}}$ & $0.13^{b}$ & $4.20^{\mathrm{a}}$ \\
\hline & Roma & Rainy & $14.22^{\mathrm{a}}$ & $9.50^{\mathrm{a}}$ & $3.55^{\mathrm{a}}$ & $10.66^{\mathrm{a}}$ & $0.28^{a}$ & $54.22^{\mathrm{a}}$ & $0.23^{a}$ & $4.17^{\mathrm{b}}$ \\
\hline & UC & Dry & $17.77^{\mathrm{a}}$ & $17.72^{\mathrm{a}}$ & $4.55^{\mathrm{a}}$ & $14.66^{\mathrm{b}}$ & $0.21^{\mathrm{b}}$ & $55.66^{\mathrm{b}}$ & $0.36^{\mathrm{b}}$ & $4.16^{\mathrm{b}}$ \\
\hline & UC & Rainy & $14.33^{b}$ & $14.83^{\mathrm{b}}$ & $2.44^{\mathrm{b}}$ & $14.88^{\mathrm{a}}$ & $0.32^{a}$ & $68.77^{a}$ & $0.45^{\mathrm{a}}$ & $4.25^{\mathrm{a}}$ \\
\hline
\end{tabular}

N.B: ${ }^{* 1}$ Means within the columns with the same letter(s) are not significantly different $(\mathrm{P} \leq 0.05)$

\section{DISCUSSION}

The distinct differences observed in most of the quantitative and qualitative traits among the sodium azide induced mutants of tomato evaluated showed significant improvements in the selected traits. Although there were few traits with no significant differences in responses to the applied treatments. In the present investigation, increased in leaf number and size due to sodium azide induced mutagenesis conformed to the earlier report by Ahloowalia and Maluszynski (2001) that, the viable mutants observed are mainly dependable measure of genetic effect in mutagen. The increased in the number of leaves, and number of fruits per plant due to sodium azide treatments is also in conformity with the work of Adamu and Aliyu (2007) who reported increased in growth and yield parameters of tomato due to sodium azide treatments.Similarly, it has been reported by Kumar etal. (2009) that chemical mutagens induce physiological damages (injury), gene mutations and chromosomal mutations in the organisms in $M_{1}$ generation (which can be measured by seed germination, survival reduction [lethality], plant height reduction (due to injury), fertility reduction or sterility (reduction in pod and seed formation). This also agrees with the findings of Deepalakshmi (2000) and ThangaHamavathy (2002) who independently reported similar effects of mutagens in black gram and Kumar etal. (2009) in cowpea. The increased in the 
number of leaves and leaf area among the mutants signifies the ability of the mutagen (sodium azide) to initiate more foliar buds. This finding agrees with the work ofMaluszynski et al. (2001) and Pasztor et al. (1985) who independently reported an increase in leaf number and leaf area among Zeamays mutants. Similar result was also reported by Nura et al. (2013) on the effect of chemical mutagen in improving the number and size of sesame leaves.

More so, the improvement in the quality traits of tomato due to sodium azide treatments is in conformity to the work of Adamu et al. (2002) when groundnut was treated with gamma rays and Sheeba et al. (2005) when gamma rays and EMS were used to treat Sesanum indicum L. where seed germination, seedling survival, plant height and pollen fertility were reduced significantly with an increase in dosage levels of both mutagens. However, in contrast, Sasi et al. (2005) showed that all plant mutant types registered lower yields compared to their parents in the study of the effects of

\section{REFERENCES}

Adamu, A. K., Oluranju, P. E., Bate, J. A., and Ogunlade, O. T. (2002): Radio-sensitivity and effective dose determination in groundnut (Arachis hypogaea L.) irradiated with gammarays. Journal of AgricultureandEnvironment3(1): 17-84.

Adamu, A. K., and Aliyu, H.(2007): Morphological effects of sodium azide on tomato(Lycopersicon esculentum Mill). Science World Journal 2(4): 912

Ahloowalia, B.S., and Maluszynski, M. (2001): Induced Mutation: A new paradigm in plant Breeding. Euphytica. 118:167-173.

Ahloowalia, B.S., Maluszynski, M., and Nicjterlein, K. (2004): Global impact of mutation-derived varieties. Euphytica.135: 187-204

Anonymous (2014): Zaria at a Glance. http://www.abu.edu.ng. Retrieved $15^{\text {th }}$ July, 2015.

Asmahan, A.M.A. (1993): Effect of Gamma Irradiation and Chemical Mutagens on Gene Expression in ZeamaysL. A Ph.DThesis (Unpublished), Department of Genetics, Faculty ofAgriculture, Ain Shams University.

Deepalakshmi, A.J. (2000): Creation of variability in black gram (Vignamungo L. Hepper) through induced mutagenesis. MSc.(Ag.) Thesis (Unpublished), Tamil Nadu Agricultural. University, Coimbatore. 1-50pp.

Dhaliwal, M.S., Kaur, A., and Singh, S. (2002): Genetic analysis and correlations involving populations derived from $L$. esculentum $\times L$. pimpinellifolium crosses of tomato. Journal of Genetics and Breeding 56:345-352.

FAO (1998): Production yearbook, Agricultural Statistics Series. FAO, Rome. Vol. 52, pp1-9. diethylsulphate and EMS on Okra (Abelmoschusesculentum (L.) var. MDU-1).

The increased in fruit quality (such as pericarp thickness, juice $\mathrm{pH}$ and fruit weight) and number due to induced mutagenesis by sodium azide signifies the vital role played by the mutagen in improving the quality traits of tomato.

\section{CONCLUSION}

It was concluded that, there is significant difference in the effects of various concentrations of sodium azide on the selected quality traits of tomato. The effect of the mutagen is significant in inducing variability that could be exploited in the improvement of highly economic crops like tomato. Lower concentration of sodium azide $(0.1 \mathrm{mM})$ was found to be more effective in improving the quality traits of tomato. It was also concluded that, the mutants and grafted tomato can be grown all the year round (both during the rainy and dry seasons).

Hille, J., Koornneef, M., Ramanna, M.S., and Tabel,P. (1989): Tomato: A crop species amenable to improvement by cellular and molecular methods. Euphytica 42: 1-23.

Kumar, V.A., Kumari, R.U., Amutha, R.,Kumar, T.S., Hepziba, S.J., and Kumar, C.R.A. (2009):Effect of chemical mutagen on expression of characters in arid legume pulsecowpea(VignaunguiculataL.Walp.). ResearchJour nalofAgricultureandBiologicalSciences 5 (6): $1115-1120$

Maluszynski, M., Szarejko, I., Barriga, P., and Balcerzyk, A. (2001): Heterosis in crop mutant crosses and production of high yielding lines, using doubled haploid systems. Euphytica. 120:387-398.

Nura, S., Adamu, A.K., Mu'Azu, S., Dangora, D.B., and Fagwalawa. L.D. (2013): Morphological characterization of colchicine-induced mutants in Sesame (Sesamum indicum L.). Journal of Biological Sciences 13 (4):277-282.

Purseglove, J.W. (1968): Tropical Crops: Dicotyledons: vol 2 Wiley New York pp 523 - 563.

Rick, C.M. (1989): Genetic Variability in Tomato species. Plant Molecular Biology Rep 1: 81 -87.

Sasi, A., Dhanavel, D., and Paradai, P. (2005): Effect of chemical Mutagensis on bhendi (Abelmoschus esculentus (L.) moench var. MDU-1). Resources on Crops 6(2) 253-256.

Sheeba, A., Abumalarmalhi, J., Babu, S., and Ibrahim, S. N.M. (2005): Mutagenic effects of gammarays and EMS in $M_{1}$ generation in sesame. ResourcesonCrops6(2): 300-306.

Thanga Hemavathy, A. (2002): Creation of variation in black gram (Vigna mungoL. Hepper). M.Sc.(Ag.) Thesis, Tamil Nadu Agric. Univ. Coimbatore. 1-79pp. 